\title{
A New Frog of the Genus Syrrhophus from the Bolivian Plateau
}

\author{
J. M. Cei \\ Instituto de Biología \\ Univer sidad Nacional de Cuyo \\ Mendoza, Argentina
}

\begin{abstract}
A new Syrrhophus (S. laplacai, new species) is described from the Bolivian Plateau, $100 \mathrm{~km}$ east of La Paz, in the Unduavi region $(3400 \mathrm{~m})$, on the borders of the tropical rain belt or "yungas." This genus of frog has not previously been reported from the Bolivian region. The affinities of the new species with $S$. montium Shreve are discussed. This latter Andean form has been recently placed by Lynch in the South American genus Niceforonia, leaving only Mexican and Central American forms in the genus Syrrhophus.
\end{abstract}

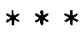

During the austral summer of 1963 I collected herpetological specimens in the mountains and high Amazonian territories of Bolivia and Peru. While exploring the eastern slopes of the Bolivian plateau, (Fig. 1), which leads down to the tropical rain belt or "yungas, "I discovered a population of a new leptodactylid frog about $100 \mathrm{~km}$ east of La Paz, on a humid rocky mountain slope (Unduavi, $3400 \mathrm{~m}$ ), overgrown with grass and bushes, and furrowed by small flowing streams. Typical tropical climax plants, such as tree ferns, Cecropia, or dense arboreal vegetation, are not present at this altitude, but they are widely distributed below 3200 $\mathrm{m}$ to the lower Yalosa River Valley $(600 \mathrm{~m})$. Small leptodactylid frogs, 10 adult and 13 young specimens, were captured individually in the late evening under large stones within a radius of some $300 \mathrm{~m}$. Air temperature and that $20-25 \mathrm{~cm}$ underground was $11^{\circ} \mathrm{C}$. Miriapods, land isopods, oligochaetes, beetles, and gonyleptids were abundant in the soil.

This paper is concerned with the systematic identity of the specimens collected, which are representatives of the neotropical genus Syrrhophus, a group not previously reported from the Bolivian plateau. I am greatly indebted to Robert L. Cei and Alfredo Laplaca, the latter from La Paz, Bolivia, who aided me during my Bolivian expedition. I will not discuss here the present status of the genus Syrrhophus Cope (1879), considered by Noble (1931) "merely an Eleutherodactylus without vomerine teeth"; affinities of both genera with Eupsophus have been pointed out (Parker, 1932)。 But in a new arrangement by Lynch (pers. comm。) many of the South American forms of Syrrhophus have been placed in the genus Niceforonia, some in Eleutherodactylus and Eupsophus.

Our Bolivian population is apparently related to the Peruvian group in which S. montium and S. juninensis (Shreve, 1938) are contained. Through the courtesy of Dr. E. Williams, during my visit to the Museum of Comparative Zoology at Harvard Univer sity, it was possible to compare the Bolivian material with the holotypes and paratypes of both montium and juninensis. The Unduavi specimens show many affinities to the types of montium. Evident differences with juninensis lie in the skin structure (smooth in juninensis, warty and granular overall in the new Bolivian form and in montium), in the belly (smooth in juninensis, granular in the other 


\section{J. M. CEI}

forms), in pigmentation (indistinct in juninensis; with evident pattern and ventral reticulation in the Bolivian specimens), in the hind limbs (somewhat shorter in juninensis) and in the metatarsal tubercles (stronger in the Bolivian specimens). Because of the recognized differences from the type and paratypes of montium, I consider the Unduavi population as a new species, related to $S$. montium Shreve, placed in Niceforonia by Lynch (pers. comm).

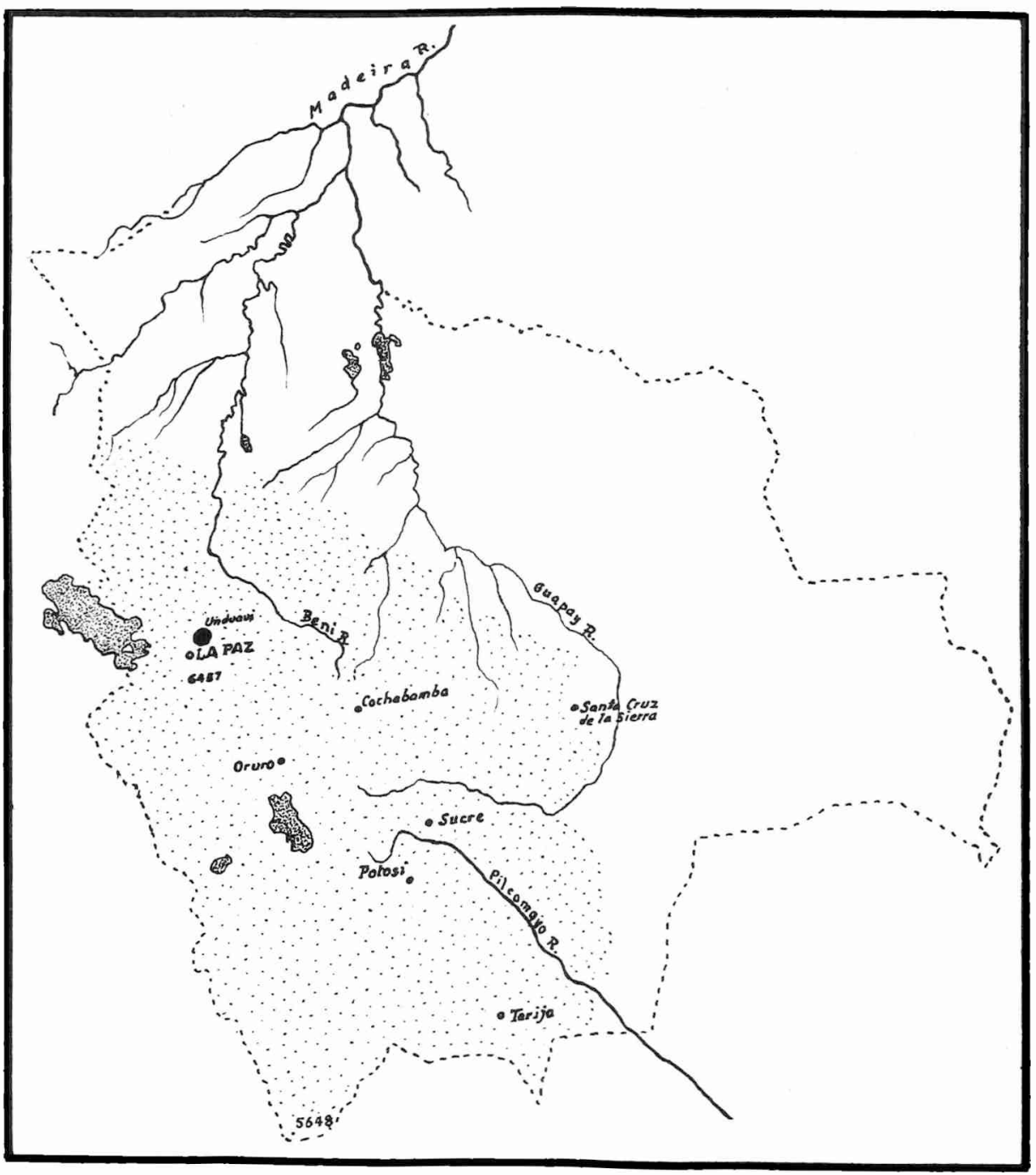

FIGURE 1. Map of Bolivia (dashed line). The stippled area shows the Bolivian plateau and Andean slopes; the black circle indicates the Unduavi region, type locality of Syrrhophus laplacai. 


\section{NEW SYRRHOPHUS FROM BOLIVIA}

\section{Syrrhophus laplacai, new species}

(Figs. 2-3)

Holotype:--Instituto de Biología, Mendoza-Universidad de Cuyo (IBM-UNC) 125l-l, male. Type locality: On the road to Coroico (National road to Beni Valley), at $3 \mathrm{~km}$ West of Pongo, in the transitional zone of Unduavi, at $3400 \mathrm{~m}$.

Allotype:--IBM-UNC 1251-2, female.

Paratypes:--IBM-UNC 1251-3 to 1251-10 (5 $0^{\circ} 0^{\prime \prime}, 3$ 우).

Diagnosis:--Allied to Syrrhophus montium, from which it differs in general coloration and in having a more protruding snout, a more distinct tympanum with an evident supratympanic fold, a broader interorbital distance, longer hindlimbs
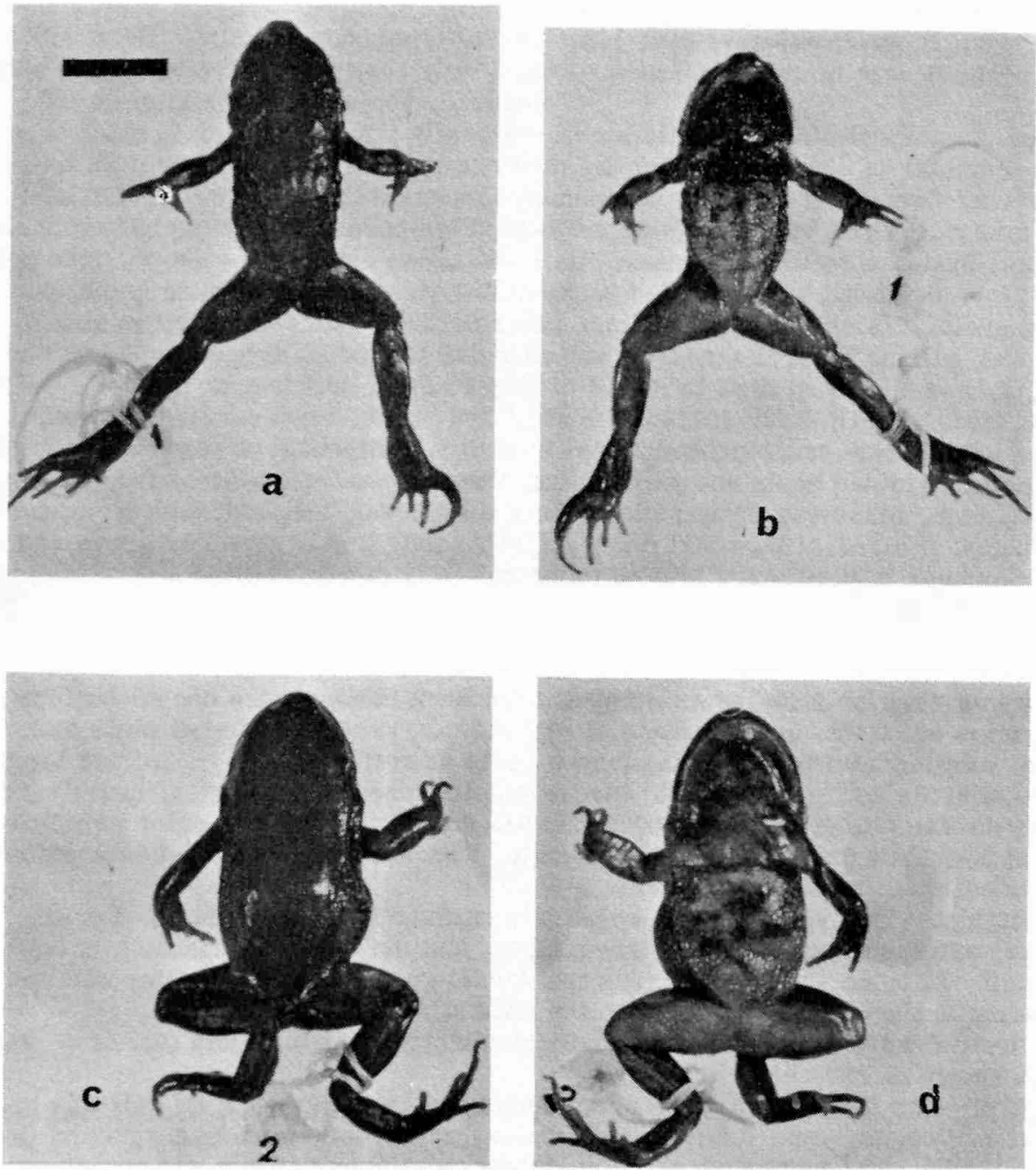

FIGURE 2. Syrrhophus laplacai, new species, a-b, holotype (male); c-d, allotype (female). Black bar equals $1 \mathrm{~cm}$. 

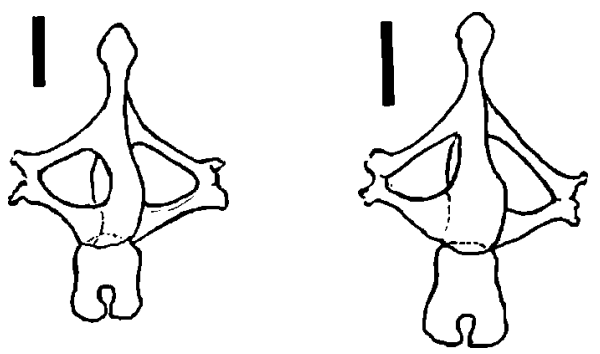

FIGURE 3. Pectoral girdles of Syrrhophus. Left, $S$, laplacai, new species (IBM-UNC 1251/8); right, S. montium Shreve (IBM-UNC 1424/2). Natural size of girdle indicated by black bars. and more granular skin.

Description:--Snout-vent length: holotype, $28 \mathrm{~mm}$ (range in 6 ơ 27-31 $\mathrm{mm}$ ); allotype, $33 \mathrm{~mm}$ (range in 4 우 28 $33 \mathrm{~mm}$ ). Measurements of holotype: tibia $11 \mathrm{~mm}$, femur $11.5 \mathrm{~mm}$, foot 17.1 $\mathrm{mm}$, head width $10 \mathrm{~mm}$, head length 10.5 $\mathrm{mm}$, interorbital distance $2.5 \mathrm{~mm}$, width of eyelid $2.0 \mathrm{~mm}$, internarial distance $1.9 \mathrm{~mm}$, diameter of eye 2.8 , diameter of tympanum $1.0 \mathrm{~mm}$. Measurements of allotype: tibia $13 \mathrm{~mm}$, femur $13 \mathrm{~mm}$, foot $21 \mathrm{~mm}$, head width $10 \mathrm{~mm}$, head length 11 $\mathrm{mm}$, interorbital distance $3.2 \mathrm{~mm}$, width of eyelid $2.2 \mathrm{~mm}$, internarial distance $2.6 \mathrm{~mm}$, diameter of eye $3.0 \mathrm{~mm}$, diameter of tympanum $1.2 \mathrm{~mm}$. Head wider than body, one third of body length; snout rounded, somewhat protruding beyond lower jaw; canthus distinct; nostrils small, laterally placed, nearer to snout than to eyes; diameter of eye greater than its distance from nostril; interorbital distance greater than width of eyelid; tympanum concealed but not indistinct; evident dermal fold from orbit curving downward behind tympanum; glandular ridges under tympanum; tongue somewhat elliptical, its width about one half its length, free posteriorly; forearm long; when carried backwards reaching and crossing groin (not crossing groin in females); outer palmar tubercle large and flat, equal in size to inner; other palmar tubercles absent; subarticular tubercles evident, one each on digits 1,2 , and 4, two on digit 3; length of fingers from shortest to longest 2-1-4-3; terminal discs slightly dilated; hindlimb stout and short, when carried forward tibiotar sal articulation reaching tympanum in males, tympanum or shoulder in females; when hindlimbs folded heels not overlapping; inner and outer metatarsal tubercles elliptical, high, massive; subarticular tubercles conical; length of toes from shortest to longest 1-2-5-3-4; terminal discs slightly dilated; skin granular above and below, glandular in the flanks; minute tubercles in tympanic region; no external evidence of inguinal gland.

Coloration:--In living specimens the dorsum is reddish brown, mottled with yellow; interocular band dark; more or less evident X-shaped dorsal brown pattern; laterally indistinct or faint brown stripes; faint dark bands on the dor sal surface of the forearms or on the upper surface of hindlimbs. Venter creamish white and purplish, mottled with faint reddish brown spots or reticulations; flanks and lower surfaces of arms and legs purplish; throat purplish cream in females, heavily pigmented with fine bluish spots in males. In alcohol, dorsal ground color pale brown with dark X-shaped pattern evident; ventrally, reticulated and mottled dark pattern more evident than in living individuals.

Variation:--The type series is relatively uniform in color pattern. Dorsal dark spots are fused more or less irregularly, and the X-shaped flecking is bold or reduced. In some living specimens the dor sal ground color is lighter with greenish blending in the canthal region or in the flanks.

Pectoral Girdle:--The pectoral girdle is slightly different from that of $S$. montium, as shown in Figure 3.

Habits:--The frogs were found under stones and underground; no call was heard. A cluster of 15 eggs, each $7.5 \mathrm{~mm}$ in diameter, was found $25 \mathrm{~cm}$ underground (temperature $11^{\circ} \mathrm{C}$ ). The eggs each had a resistent gelatinous capsule and contained a small, well-developed froglet ready to hatch. Hatching occurred five days later; the average $\mathrm{s}-\mathrm{v}$ length of a hatchling is $7.5 \mathrm{~mm}$. 


\section{DISCUSSION}

The morphological characters mentioned above seem to be sufficient to establish the specific status for these terminal populations of the genus Syrrhophus on the South American continent. This represents the southernmost area reached by this leptodactylid genus, so far as known. This new species is well separated mor phologically from Syrrhophus montium by its more granular skin, its granular belly, its well-developed supratympanic fold, its broader intertimpanic distance and its well-marked dorso-ventral pattern.

The ecological conditions of the Peruvian tropical realm, habitat of S. montium and $S$. juninensis are not dissimilar from the Bolivian "yungas。" The type locality for the new species lies some $1500 \mathrm{~km}$ from that of montium. Probably other populations of the same genus may be found bordering the intermediate or transitional areas facing the tropical humid forest which surrounds the Peruvian and Bolivian plateau between $12^{\circ}$ and $16^{\circ}$ South Latitude, in the high Ucayali and Madre de Dios basins.

\section{LITERATURE CITED}

Cope, E. D. 1897. Eleventh contribution to the herpetology of tropical America. Proc. Amer. Philos。 Soc, 18(104): 261-277.

Noble, G. K. 1931. The biology of the Amphibia. McGraw-Hill Book Co., New York. $577 \mathrm{p}$.

Parker, H. W. 1932. The systematic status of some frogs in the Vienna Museum. Ann. Mag. Nat. Hist, , ser. 10, 10(58): 341-344.

Shreve, B. 1938. A new Liolaemus and two Syrrhopus [Sic] from Peru. Jour. Washington Acad. Sci., 28(9): 404-407. 
